\title{
Pietro Tacchini as meteorologist: his correspondence kept in the UCEA archives
}

\author{
Franca Mangianti De Angelis $\left({ }^{1}\right)$ and Cesare Mangianti $\left(^{2}\right)$ \\ (') Ufficio Centrale di Ecologia Agraria (UCEA), Roma, Italy \\ (2) Società Meteorologica Italiana (SMI), Bussoleno (Torino), Italy
}

\begin{abstract}
The present work concerns Tacchini's activity during the years 1879-1899, while he was director of Rome's Ufficio Centrale di Metereologia (Central Office of Meteorology-UCM) now called Ufficio Centrale di Ecologia Agraria (UCEA-Central Office of Agricultural Ecology). Even if that is only a limited part of Tacchini's work, we believe it is extremely interesting to investigate the studies he carried on, in order to bring to light the innovations he introduced in the meteorological field. The huge amount of letters of of the Tacchini's epistolary preserved at the UCEA allow us to improve the scientific biography of this very important earth scientist.
\end{abstract}

Key words Pietro Tacchini-UCEA - correspondence - history of meteorology - history of geodynamics

\section{Tacchini's career and studies}

The aim of this work is to summaryze Pietro Tacchini's studies, activities and his scientific carreer (fig. 1). Tacchini's studies cover a variety of interests, dealing with different fields of science: astronomy, meteorology and seismology. As a consequence, the amount of his scientific production is huge, including five hundred published works.

Having taken his degree in engineering at the University of Modena, in 1857 he began his activity, which he carried on until 1899 when he resigned as director of the Ufficio Centrale. He

Mailing address: Dr. Franca Mangianti De Angelis, Ufficio Centrale di Ecologia Agraria (UCEA), Via del Caravita 7/A, 00186 Roma, Italy; e-mail: fmangianti@ucea.it worked in several sites: from 1857 to 1859 at the Padua astronomical observatory, under Santini's guidance; from 1859 to 1863 he was director of the Modena astronomical observatory; from 1863 to 1879 , assistant astronomer at the Palermo observatory. In 1879, in Rome, he was appointed as first director of UCM with annex observatory. In 1899 he gave up his activity as director of the UCM, still keeping the astronomical observatory honorary direction. In 1902 he gave up his activity completely, left Rome and moved to Spilamberto (Modena), his native town.

Our report deals with Tacchini's meteorologist activity over the years 1879-1899, while he was director of the Ufficio Meteorologico.

Before Italy's unification, meteorological observations were collected in different Italian sites and neither comparison nor correlation between data were made. At the same time as the realization of the Papal States meteorological network in Piedmont, in 1865 the Ufficio Centrale di Meteorologia Marittima (Central Office of Maritime Meteorology) was founded in Florence for assistance to cargo activity. All these 


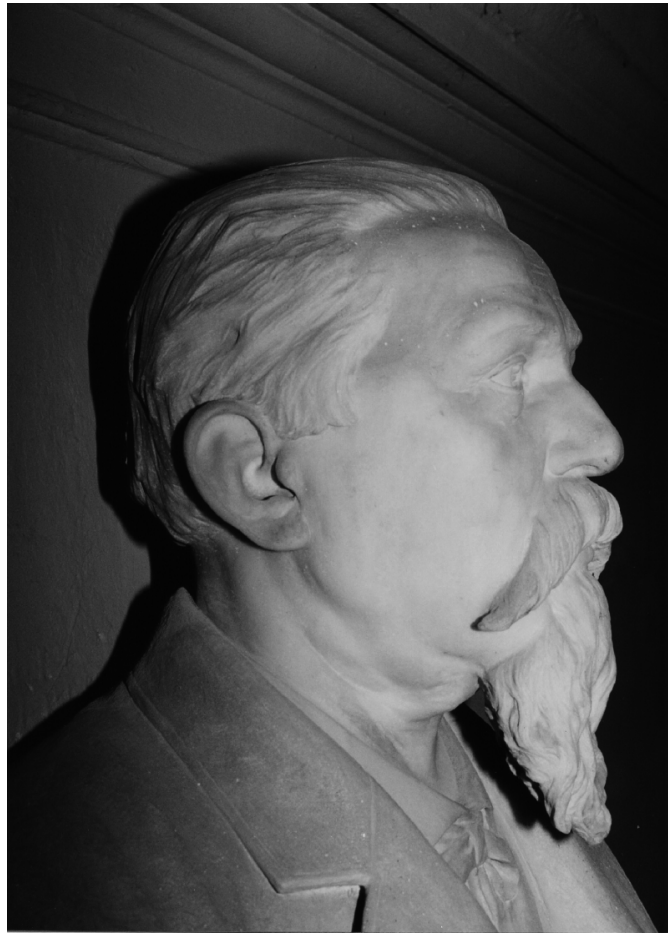

Fig. 1. Pietro Tacchini.

initiatives were autonomous, without any connections with each other. Italy, after the unification (in 1861) became one country and realized that there were common aims and social interests. On 26th November 1876 the Italian government founded the UCM, which can be considered the first attempt to realize a unique national meteorological service. The Office, located in the Collegio Romano, began its activities in May 1879. After father Secchi's death, the annexe astronomic observatory became the property of the Italian government. Its first director was Pietro Tacchini. Tacchini, in addition to scientific qualities, displayed unexpected an diplomatic disposition and important managing activities. He realized an institution that competed with foreign observatories. For this reason he allowed the existing meteorological organizations to keep their autonomy, supplying them with money, instruments and forms. He

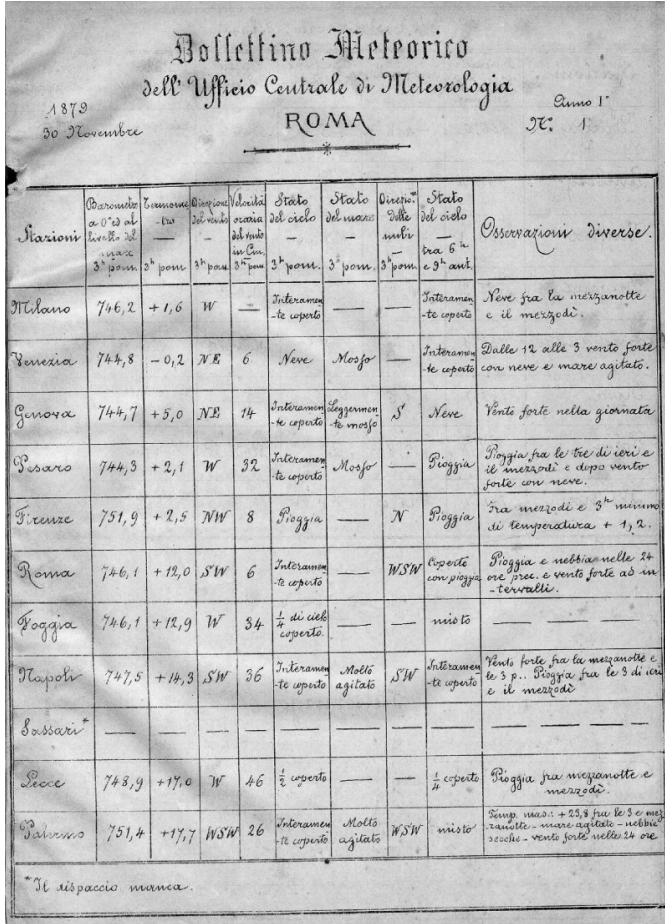

Fig. 2. Bollettino Meteorico 30th November 1879 first issue.

asked them, in exchange, to send back meteorological data. After processing, these data were published in La climatologia d'Italia and in Bollettino meteorico, which began its publications on 30th November 1879 (figs. 2, 3, 4).

Tacchini organized the office in five divisions: instruments calibration, climatic studies, weather forecast, seismology and agro-climatology.

He published the monthly Bollettino meteorico internazionale, with observations coming from several foreign stations, and a bulletin with agrarian news named Servizio meteorico agrario in 1877, which became the Rivista meteorico agraria a few years later. At present the entire collection of publications is in the UCEA's library.

Tacchini studied not only meteorology, but he also carried on studies of geodynamics. Under his guidance geodynamics had a great devel- 


\begin{tabular}{|c|c|c|c|c|c|c|}
\hline \multicolumn{7}{|c|}{ Anstriax ore ; sol mati: } \\
\hline Staxioni & 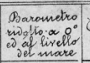 & Genperatio & 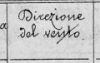 & $\begin{array}{l}\text { Touraa } \\
\text { Solvento }\end{array}$ & $\begin{array}{l}\text { Strato } \\
\text { ainosferico }\end{array}$ & - Sel mato \\
\hline Graga & 756,0 & $-4,6$ & s & Debole & $\begin{array}{l}\text { Cieco tutto } \\
\text { coperto }\end{array}$ & \\
\hline Lemberg & 756,4 & $-4,2$ & $s^{\prime}$ & Debole & $\begin{array}{l}\text { Cievorthitc } \\
\text { copperto }\end{array}$ & \\
\hline giemna & 756,9 & $-8,2$ & Calma & - & $\begin{array}{l}\text { Cielo vurto } \\
\text { copperto }\end{array}$ & \\
\hline Bregenz & 755,3 & $-6,8$ & r & Debore & $\begin{array}{l}\text { Cielo tutto } \\
\text { coperto }\end{array}$ & \\
\hline Hermanstait & 755,1 & $-6,2$ & II & Mescrato & Seve & \\
\hline Kiva & $7+8,4$ & $+1,6$ & Calma & - & $\begin{array}{l}\text { Ciclo turto } \\
\text { copecto }\end{array}$ & 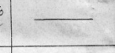 \\
\hline Gొola & 746,4 & $+2,8$ & Fi & Shoserato & Sioggaia & Ogitato \\
\hline Sesina & 746,1 & $+14,0$ & $S E$ & Yrescor & $\begin{array}{l}\text { Cide tutto } \\
\text { copperto }\end{array}$ & Ayitato \\
\hline \multicolumn{7}{|c|}{ Tielroburgo } \\
\hline 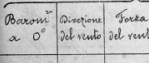 & 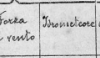 & 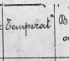 & 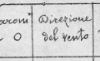 & 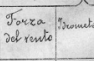 & 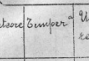 & 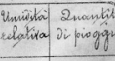 \\
\hline 748,2 N & 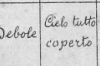 & $-13,5$ & $50,9 S E$ & Debole coupt & $\begin{array}{l}\text { turet } \\
\text { erte }\end{array}$ & $87 \mathrm{pen} \%$ \\
\hline
\end{tabular}

Fig. 3. Bollettino Meteorico first issue pag. 2 .

opment. That is the reason the Ufficio Centrale changed its name by Regio Ufficio Centrale di Meteorologia e Geodinamica (UCMG) on June 1887. Tacchini's idea to found a museum of sismometria - the topical subject of his paper Antichi strumenti sismici appeared on Bollettino sismologico in 1898 - is explained in the following words: «Nobody can understand how important collecting and keeping these ancient instrumentsis. They were the forerunners of today's and are necessary for describing the history of seismometry. In the same way, as we collected the ancient instruments of astronomy, that we are going on collecting and keeping in Museo Copernicano, my idea is to do the same for the seismological ones collecting them in a new museum located in Ufficio Centrale di Meteorologia e Geodinamica». One century later, the museum has not yet been realized.

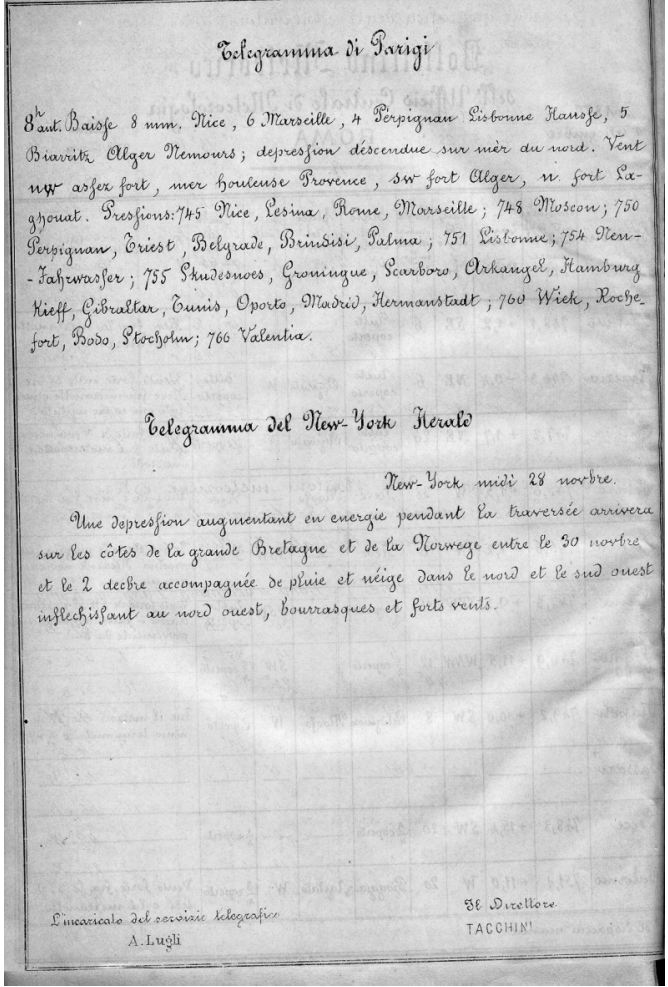

Fig. 4. Bollettino Meteorico first issue pag. 3.

\section{Tacchini's papers and pubblication}

Tacchini proved also to be a good manager. At the International Congress of Meteorology, Rome 1879, he contributed with innovative ideas to coordinate the national meteorological services, founding Italy's Istituto Meteorologico Centrale and becoming its first director. $\mathrm{He}$ chose an elegant seat, the Collegio Romano, and engaged young and skilful co-workers such as Millosevich, Chistoni, Ferrari Ciro and Lugli. Thanks to his guidance the office could compete with the best institutes in Europe.

Many daily and periodical publications were published concerning both scientific and practical subjects, like the operative management of data and meteorological stations. We can mention: daily meteoric bulletin, the decade agrometeorological review and Annals of Ufficio Cen- 


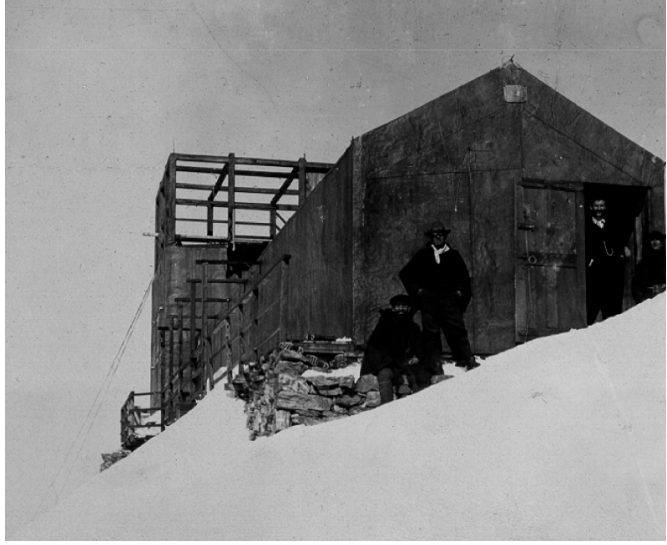

Fig. 5. Outside Capanna Margherita.

trale di Meteorologia. This collection contains a large amount of data and bibliography concerning meteorology and geophysics.

The following are some of the most important Tacchini's papers published in Annali di Metereologia.

Il clima di Roma: a complete review published in 1882. Tacchini presents all meteorological data recorded in the Collegio Romano since 1855 and 1861. This work is the basis for later works made by Eredia, Roncalli and many other researchers using this database.

Malarian fever and meteors in Rome region: treating this subject in 1884 , Tacchini was a forerunner. He understood the influence of climate on human health, today a topical issue with studies trying to establish relationships between climatic environment and diseases.

Massaua clime: this work is a report done for the former Ministry of the war. It is an indepth analysis of the meteorological observations made in the Massaua observatory in 1885. The instruments, part of the Italian colonies network, were supplied by the Ufficio Centrale.

Snow in Rome January 1880 and 1891: snowy weather is not frequent in Rome, the data recorded by Tacchini have been recently used by Roncalli, Mangianti and Beltrano to update to 1990 a complete file of snow-falls in Rome.

Sunshine in Rome 1887-1895: this work presents a complete record of sunshine days and hours in Rome done with Campbell Stokes

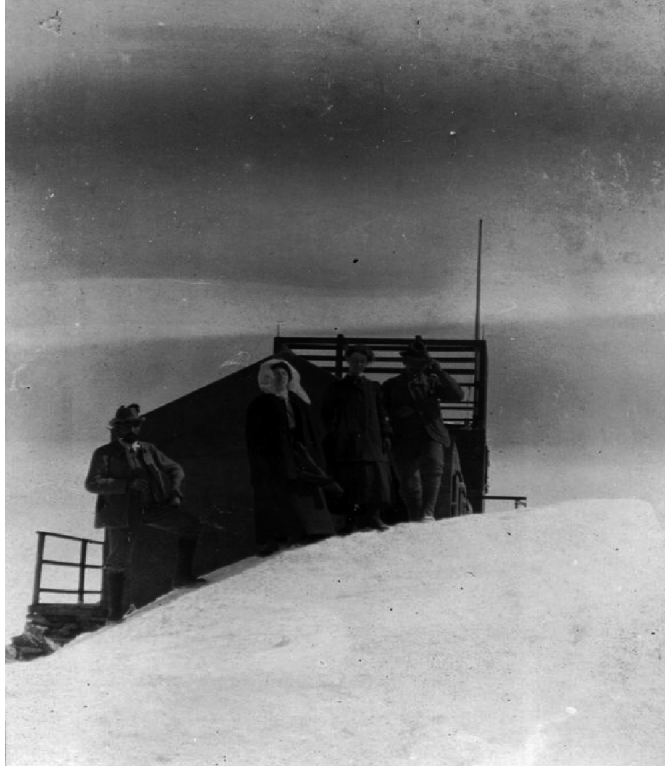

Fig. 6. Queen Margherita's visit to Capanna Margherita.

shine recorder. The idea to record sunshine was quite new. At that time, indeed, only temperature and rainfalls were registered.

Seeds and sand rainfalls: the paper describe April 24th 1897 rainfall. Seeds and sand were carried from the Sahara desert and it was a typical African perturbation that reached Italy.

Very important was Tacchini's commitment to found many important observatories all over Italy, especially the ones located at high altitude. We mention, first of all, the Etna observatory which supplied meteorological data of high altitude. Sestola, Monte Cimone and in the last period of his activity the Monte Rosa observatory, Capanna Margherita, the highest in Europe (figs. $5,6,7$ ). It was very important and useful, even today, for glacier studies. In a paper we learn how Tacchini's will to realize these sites was very uneasy due to the lack of money, to say nothing about the difficulties of building an observatory at 4942 m.s.l. The realization of the Monte Cimone observatory was due completely to his will. The first idea dates back to 1852 . In 1876 the Italian government and Club Alpino tried to realize it but were unsuccessful (fig. 8). When Tacchini moved 


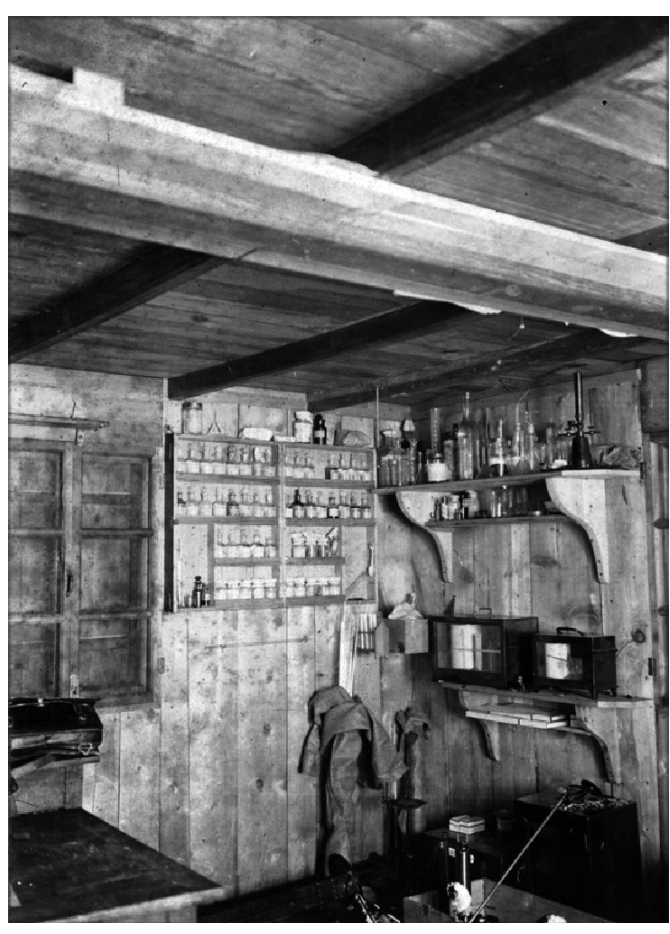

Fig. 7. Inner room and instruments of Capanna.

from Palermo to Rome in 1880 he received the task of building a tower in Monte Cimone. As director of the Ufficio Centrale per la meteorologia, he reached the aim to build it annexed to Sestola Observatory. The opening was in 1892.

This paper only concerns Tacchini's activity as a meteorologist during the period as director of Ufficio Centrale and this is only a very small part of his works. Reading Tacchini's many papers we discovered and realized that his work, studies and research in astronomy were predominant and very extensive.

\section{Pietro Tacchini's scientific and personal correspondence}

Like most of the great scholars of his times, Pietro Tacchini had an intense epistolary relationship with a large number of Italian as well as foreign scholars from various sectors of the sciences. By virtue of his role as director of the

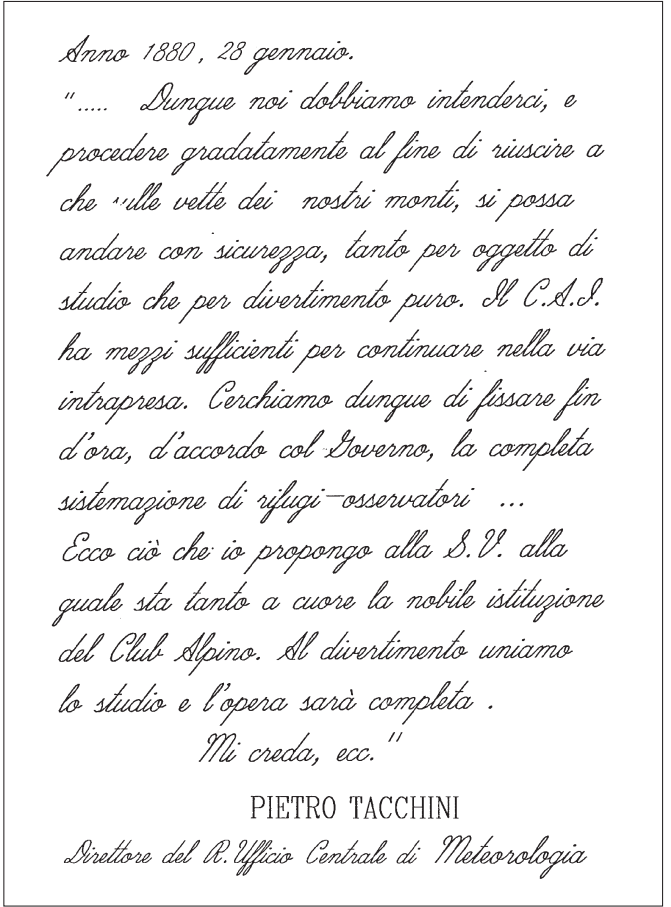

Fig. 8. Tacchini's letter to Quintino Sella president of CAI (Club Alpino Italiano) regarding the building of Capanna Margherita on Monte Rosa.

UCM (later UCMG), we should add to these correspondents the people in charge of public and private institutions, politicians and leading cultural figures. It is through this dense network of relations that it was possible for Tacchini to assure Italy a meteorological service first and then a geodynamic one as well, up to the standard of the other European countries and the study tradition until then guaranteed by networks of private scholars or those operating within the ecclesiastic colleges or the universities.

The UCEA library alone preserves more than 5,000 letters that he had received, from 1860 to 1901 , from more than 1,000 correspondents, some 300 of whom foreign.

The epistolary, wholly reproduced in digital format by SGA - Storia Geofisica Ambiente of Bologna, within the scope of the TROMOS Project (INGV-SGA 1990-2007) is currently the subject of study by numerous scholars from 


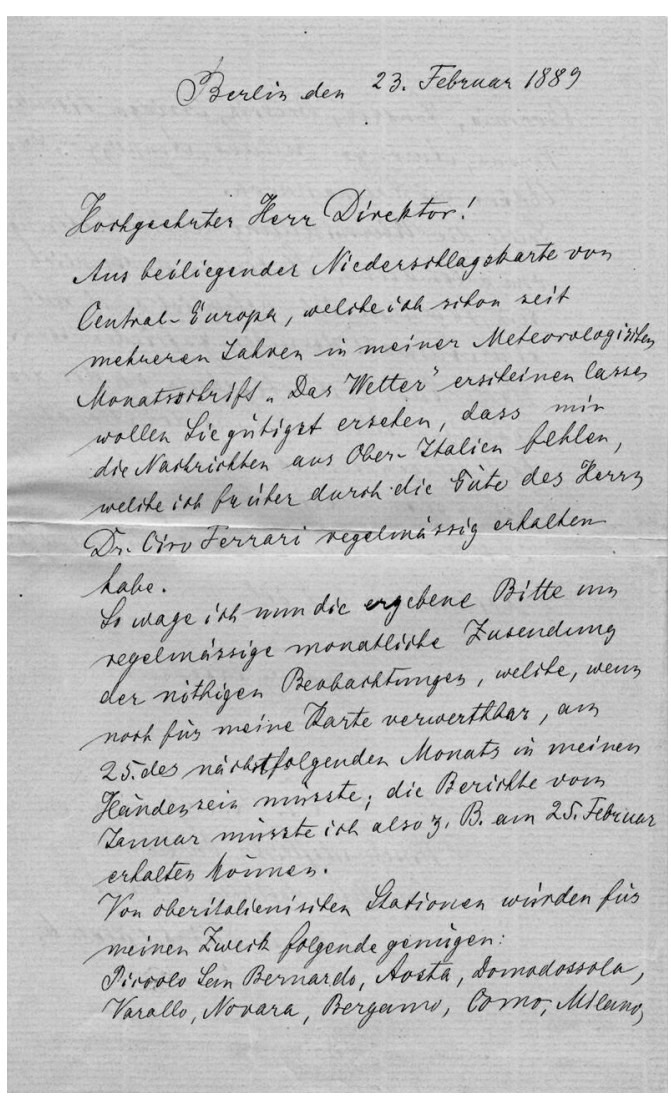

Fig. 9. Tacchini's correspondence with german scholar.

a range of disciplines which Tacchini dealt with in different ways.

The epistolary archive is the largest one preserved at the UCEA, in which the institutional, scientific, political and private correspondence is mixed together. Tacchini's role in the birth and the development of the national services of meteorology and seismology in Italy, the substantial integrity of the archive, practically untouched up until the time of its reproduction, make this documentation extremely important for Tacchini's scientific and human biography and for the disciplinary history of meteorology, astronomy and seismology in Italy in the second half of the 19th century.

In this respect, this important archive has

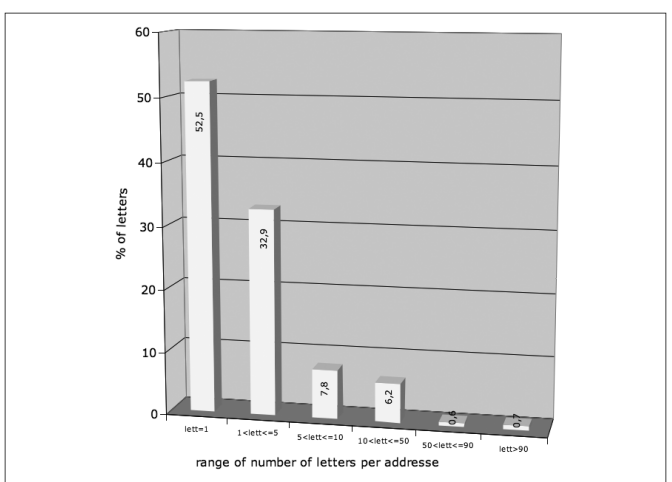

Fig. 10. Tacchini's letters statistical distributions.

been made available to scholars, with greater effectiveness particularly after its reproduction and it has so far contributed to outlining the figure of Tacchini better, but also that of some of his correspondents. As a preliminary step, it is possible here to sum up some statistical data relating to the size of some of the correspondence between the Italian and the foreign scholars (fig. 9). As has been said, Tacchini had about one thousand public and private correspondents in this epistolary fund, some $30 \%$ of whom foreign. Over $50 \%$ of the correspondents are present with just one letter in the Tacchini epistolary fund, while as many as $1.3 \%$ of the correspondents is present with over 50 letters, seven of whom with more than 90 (fig. 10).

\section{REFERENCES}

Buffoni, L. Proverbio and E. Tucci, (2000): P. Pietro Tacchini: Lettere al Padre Angelo Secchi (1861-1877), (Università degli studi di Milano, Istituto di Fisica Generale Applicata).

Chinnici, I. (1993): Pietro Tacchini: Ingegnere, Astrofisico, Meteorologo, una prima ricostruzione biografica, (Tesi di laurea).

Lorenzoni, G. (1905): Necrologio di Tacchini, Atti Ist. Veneto $S c$., Lett. A.

LugLi, M.U. (2001): Astronomi modenesi tra Seicento e Novecento: Pietro Tacchini, (Ediz. Il Fiorino, Modena).

Millosevich, E. (1905): Necrologio di Tacchini, Atti Acc. Naz. Lincei Rend., s.V, XIV.

Palazzo, L. (1904-1905): Necrologio di Tacchini, Boll. Soc. Sism. It., $\mathbf{X}$.

RIcCò, A. (1905): Necrologio di Tacchini, Mem. Soc. Spettr. It., XXXIV, Osservazioni e Memorie del R. Osservatorio Astrofisico di Arcetri, 19. 